\title{
Korai eredményeink a radiusfej töréseinek Sanatmetal protézissel való kezelésével
}

\author{
DR. CSONKA CSABA, DR. NAGY OLIVÉR, DR. KOPINEC ANDRÁS \\ DR. VARGA VILMOS
}

\section{ÖSSZEFOGLALÁS}

A szerzők osztályukon 2015 óta alkalmazzák a Sanatmetal radiusfej protézist rekonstruálhatatlan radiusfej törések, valamint a könyök „terrible triad” sérüléseinek kezelésére. Az eltelt idő alatt 16 betegnél végeztek protézis beültetést. Közleményükben összefoglalják a protézis beültetés indikációit, a mútéti technika buktatóit. Betegeiket a Mayo Klinika által használt könyök funkcionális utánvizsgálati teszttel vizsgálták. Beszámolnak a korai időszak utánvizsgálati eredményéről. Tapasztalataik alapján javasolják minden olyan esetben a radiusfej protézis beültetését, amikor a törött radiusfej rekonstrukciójára nincs lehetőség, valamint egyidejüleg a könyök instabilitása is észlelhető. A radiusfej reszekcióját csak szúk indikációval tartják elfogadhatónak.

\section{Kulcsszavak: $\quad$ Arthroplastica; Ízületi protézis; Könyöksérülés; Protézistervezés;} Radiusfej protézis; Radiustörés;

Cs. Csonka, O. Nagy, A. Kopinec, V. Varga: Our early results of the treatment with Sanatmetal prosthesis implantation in case of radial head fractures

Authors have been using Sanatmetal radial head prosthesis for treatment of unreconstructable radial head fractures and the "terrible triad" injuries since 2015. During this period they made prosthesis implantation on 16 patients. In their article they summarize the indications of prosthesis implantation and the possible technical failures during the operation process. In the early post-operative period their patients were examined by Mayo Elbow Functional Score. They present their results. Based on their experiences they suggest radial head prosthesis implantation not only in every case, when there is no possibility for the reconstruction of radial head, but also when the instability of the elbow joint can be also perceived at the same time. They find acceptable the radial head resection only within very limited indications.

Keywords: $\quad$ Elbow Joint - Injuries/Surgery; Elbow Prosthesis; Prosthesis design; Radius - Surgery; Radius fractures - Surgery; 


\section{BEVEZETÉS}

A radiusfej törése az összes törés körülbelül 4\%-át teszi ki. Ha csak a könyöksérüléseket vizsgáljuk az előfordulási arány 20-30\% (1). Általában nyújtott könyök mellett extendált és pronált csuklónál, tenyérre esés közben keletkezik. A radiusfej törések mellett $80 \%$-ban kísérő sérülések is előfordulnak, például az ulnaris collateralis szalag rupturája, a processus coronoideus ulnae törése, vagy a könyök subluxatiója, ficama (3). Az elmozdulás nélküli töréseket - ha kísérő sérüléssel nem társul konzervatívan kezeljük. Az esetek jelentős része az ízületi haemarthros leszívása és az ízület Lidocainnal feltöltése, valamint átmeneti kartartó heveder rögzítéssel, majd korai irányított tornával jól kezelhető. Az ízületi lépcsőképződéssel járó, diszlokált töréseket törekszünk csavaros osteosynthesissel anatómiai helyzetben, stabilan fixálni. Amennyiben a radiusfej rekonstrukciójára nincs lehetőség, vagy a törés jellege olyan, hogy a fej vérellátását veszélyezteti (tuberositas radii-ra terjedő), illetve ha a törés osteosynthesise csak kompromisszumok árán oldható meg, jobbnak tartjuk a primeren elvégzett protézisbeültetést. A radiusfej reszekciót csak igen beszűkült indikációval, idős, keveset mozgó betegek nem domináns végtagján tartjuk elfogadható mútéti megoldásnak.

$\mathrm{Az}$ első radiusfej protézist Speed ültette be 1941-ben (cit. 8). Hazánkban Pap Károly 1954-ben acrylatból készült fejjel végzett műtétet (cit. 8). A korai próbálkozások ellenére 1970 előtt a fej reszekció volt az elterjedt mútéti megoldás. A fej reszekciók után - mint arra több szerző felhívja a figyelmet - gyakori késői szövődmények kialakulását észlelték $(5,8,11)$. A radiusfej protézisek 1970 után kezdtek elterjedni (1).

\section{ANYAG ÉS MÓDSZER}

A 2015. június 15. és 2019. május 31. közötti időszakban 36 radiusfej törött beteget operáltunk. Közülük 16 esetben kellett protézisbeültetetést végeznünk. Radiusfej törésének klinikai gyanúja esetén anteroposterior (AP), laterolateralis (LL) és 45 fokos szögben készített röntgenfelvétel (1. a-c ábrák) és csukló (AP) felvétel elkészítése javasolt (Essex-Lopresti sérülés kizárására). A felvételek értékelése közben gondosan keresni kell a kísérő sérülések, például processus coronoideus ulnae, sérülését.

A törés jellegének megítélésében a rutin háromirányú röntgenfelvétel sokszor megtéveszthet bennünket. Bizonytalanság, nem pontos megítélhetőség esetén, valamint a mútét megtervezéséhez a CT vizsgálat elvégzése sokszor nélkülözhetetlen. Ha a vizsgálatok alapján felmerül a három vagy több rész törésének lehetősége, a műtét előtt fel kell készülnünk a protézisbeültetésre (2. a-e ábrák).

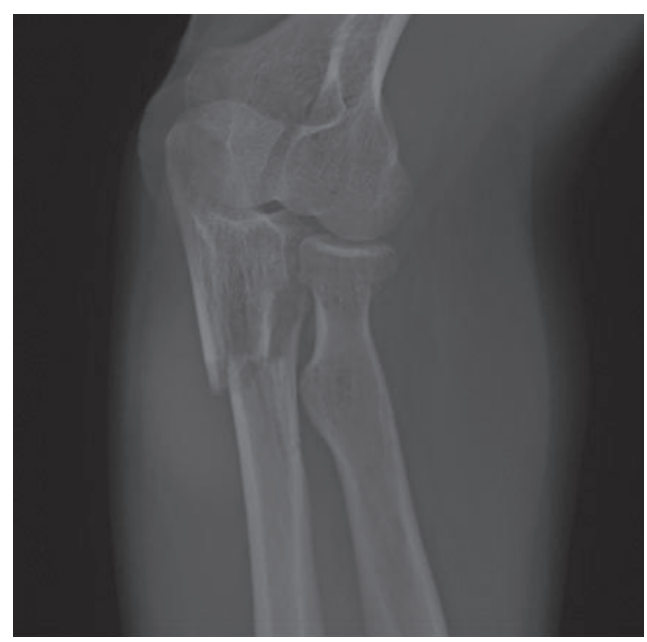

1. a ábra

AP könyök felvétel, melyen az ulna proximalis vég darabos törése látszik, a radiusfej több rész törése viszont csak sejthetö 


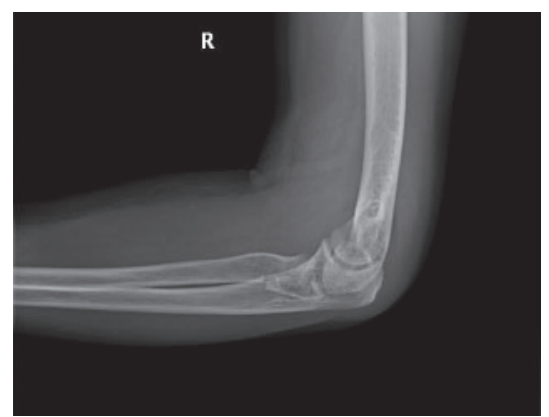

1. b ábra

Ugyanazon beteg LL könyök röntgenfelvétele
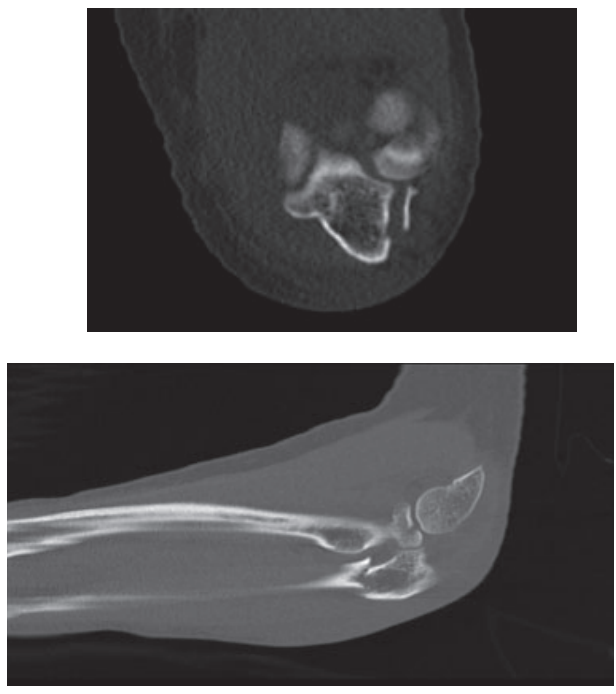

a

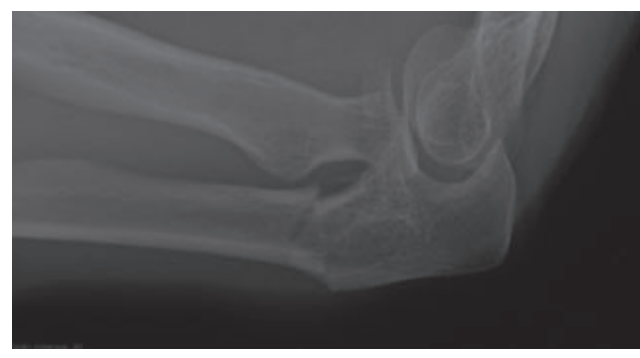

\section{1. c ábra}

Az elöző beteg 45 fokban rotált helyzetü könyökfelvétele

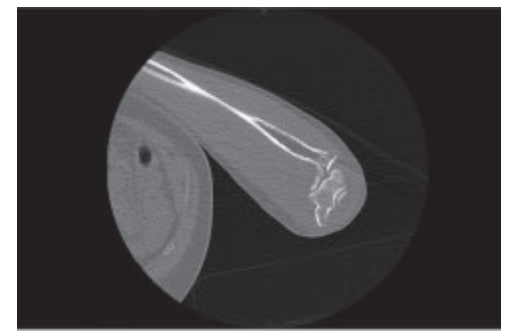

b

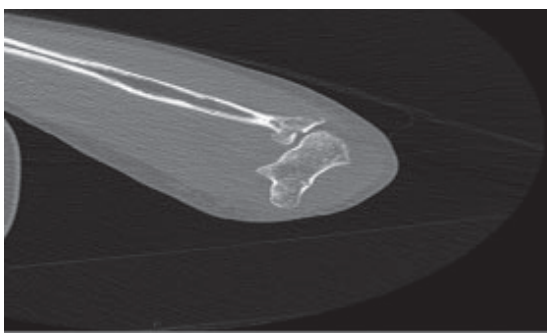

d

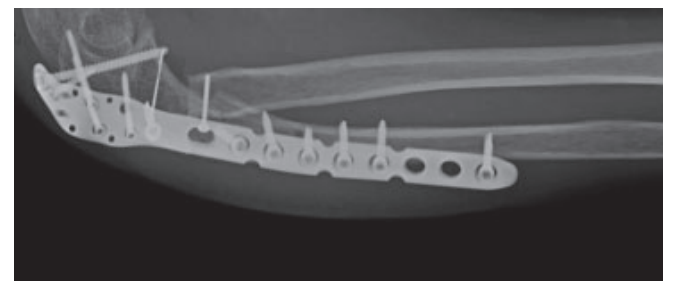

e

\section{2. a-e ábrák}

A betegről elkészített CT felvételeken volt látható, hogy a radiusfej több részre törött, valamint az e ábrán a posztoperativ 6 . hetes $L L$ röntgen 


\section{MÜTÉTI TECHNIKA}

A radiusfej mütéteinél kétfajta feltárást alkalmaztunk. A Kaplan-féle direkt lateralis feltárást vagy a Kocher-féle feltárást (2). A mútétnek két sarkalatos pontja van. Az első a reszekció mélységének és a reszekciós sík szögének megválasztása, a második a protézis fej méretének pontos meghatározása. A fej méretének megválasztásához külön sablont készítettünk. Ebbe a több részre törött fejet puzzleként összerakva tudjuk az eredetivel azonos protézis fej nagyságot kiválasztani (3. ábra). A reszekció mélységének meghatározásához a behelyezendő protézist használjuk. Fontos, hogy a beültetett protézis fej 1-2 $\mathrm{mm}$ távolságban legyen a capitulum humeritől. A reszekciós síkot úgy kell megválasztani, hogy supinált kéz mellett lateral felé nyitott 100 fokos szöget zárjon be a radius tengelyével.

A reszekció mélységének megválasztásánál figyelembe kell venni a ligamentum quadratum helyzetét, mely szalagot a stabilitás érdekében minden körülmények között meg kell őrizni (4. ábra). Amennyiben a szalag sérült, fokozott

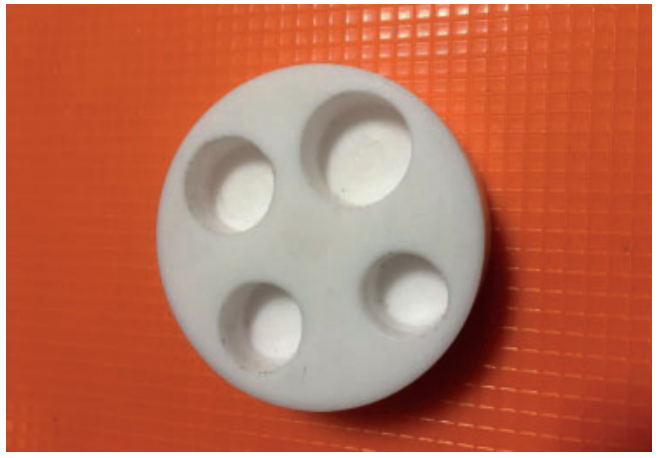

3. ábra

Az általunk készített sablon, a darabosan törött radiusfej eredeti méretének meghatározásához figyelmet kell fordítani a ligamentum anulare rekonstrukcióra.

Mútéteinknél Sanatmetal protéziseket használunk, négyféle fejméret közül választhatunk (5. ábra). Az "A" a legkisebb, a "D” a legnagyobb fejméret. A szár helyét $6,5 \mathrm{~mm}$-es spongiosa menetvágóval készítjük elő, majd a behelyezett protézisszárat egy darab 1,5 mm-es mini csavar haránt bevezetésével rögzítjük (6. $a-b$ ábrák). Ezt követi a mozgástartomány, és a stabilitási próba.

A mútét után a kart 3 hétre kartartó hevederben rögzítjük, de az irányított mozgásgyakorlatokat már a posztoperatív 2. napon megkezdjük. Mind a flexió-extenzió, mind a pro-supinatio tartományban a mozgatást a fájdalommentességig megengedjük. A harmadik hét végére igyekszünk a teljes mozgástartományt elérni. A terhelést hat hét után engedjük meg.

A heterotop ossificatio kialakulásának megelőzésére napi kétszer $40 \mathrm{mg}$ Indomethacint adtunk szájon keresztül, a mútét napján indítva, 6 héten át.

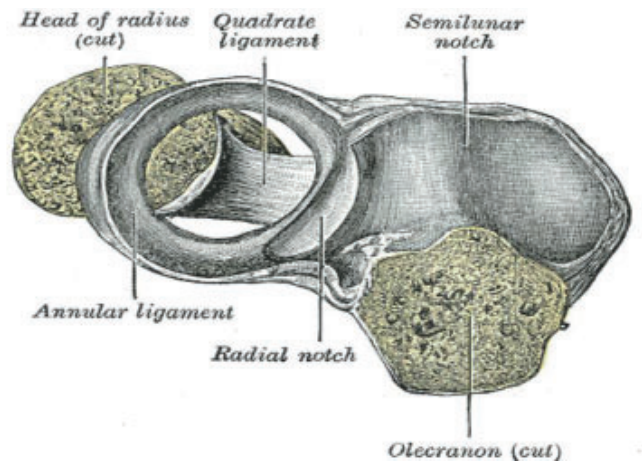

4. ábra

Haránt metszet a könyökröl a ligamentus anulare magasságában (cit. 6.)

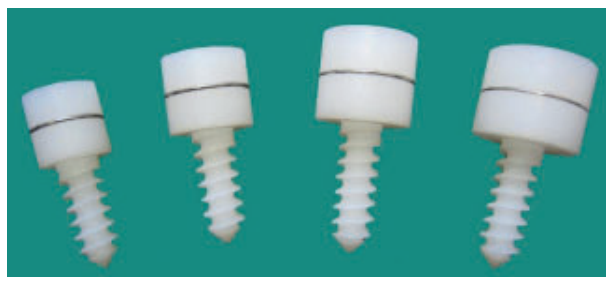

5. ábra

Sanatmetal radiusfej protézis sorozat 

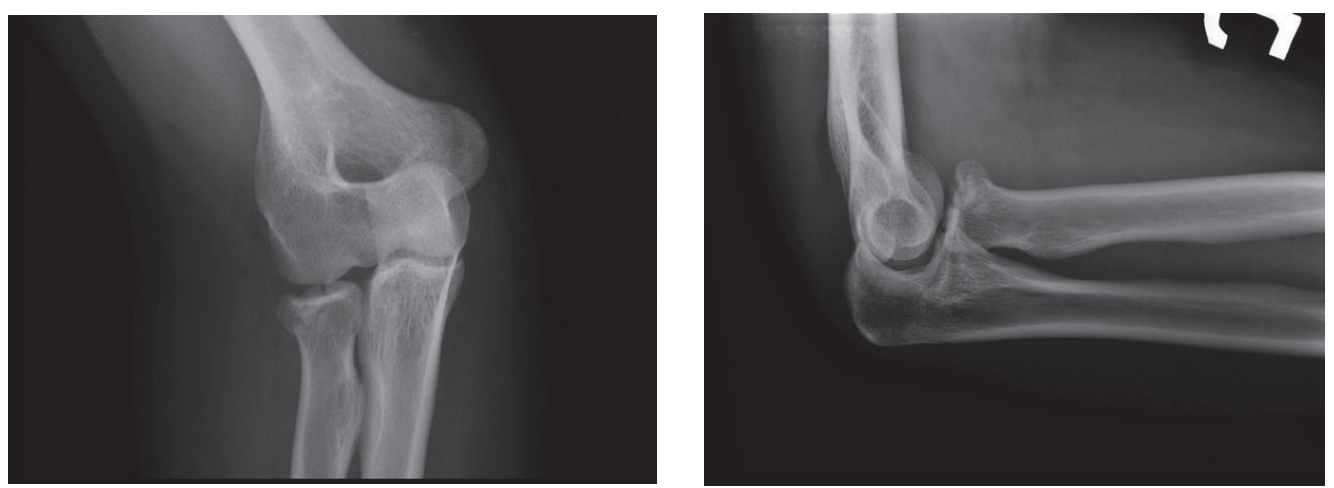

6. a ábra

Mütét elötti röntgenfelvételek

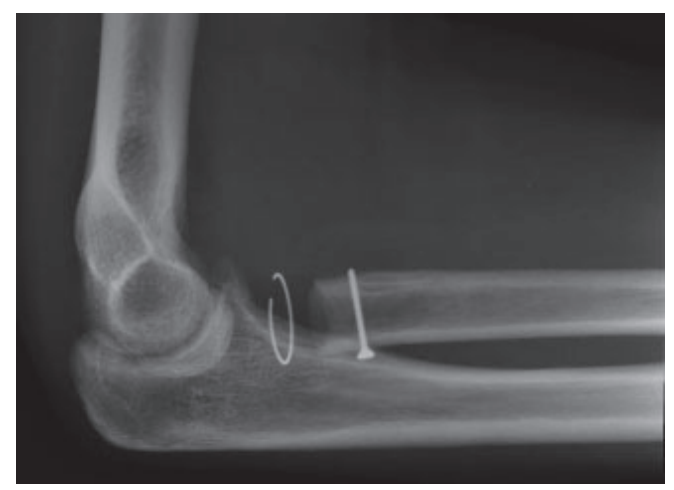

6. $b$ ábra

LL könyök röntgenfelvétel a jelölö gyürüvel és a szárat rögzítő 1,5 mm csavarral

\section{EREDMÉNYEK}

Korai posztoperatív szövődményünk (sebfertőzés, korai kilazulás, implantátum törés) nem volt. Két esetben kényszerültünk reoperációra. Az első esetben a periprotetikus meszesedés miatt a meszes szövet excisióját, release mútétet végeztünk. Ezt követően a mozgások rendeződtek. Egy másik esetben a mútétet követő 40 . hétben purulens ízületi arthritist, sipoly kialakulását észleltünk. Ez a betegünk többszörös könyökficam és darabos radiusfej törés miatt került mútétre. $\mathrm{A}$ mútétnél temporer ízületi áttǔzése is történt. A drót a bőrt perforálta és mellette felületes gyulladás alakult ki. Nála a 43. héten a protézis eltávolítását, ízületi debridement-t és fixateur externe felhelyezést végeztünk. Sebe gyógyult, ficama nem ismétlődött. Könyök mozgásai beszúkültek.

Betegeinket 2019 júliusában felülvizsgáltuk. A Mayo Klinika által publikált „Elbow Functional Score” alapján történt a vizsgálat (I. táblázat). Az utánkövetési idő 2-36 hónap volt. A 16 beteg közül 15 beteget tudtunk értékelni. Az átlagpontszám 84,23 pont volt, 5 és 100 közötti szórással, 10 betegünk került a kiváló, 4 beteg a jó és 1 beteg a rossz kategóriába. Legfiatalabb betegünk 20 éves, a legidősebb 74 éves volt. Az átlagéletkor 50,75 év volt. Betegeink közül 3 férfi és 13 nő volt. 
I. táblázat Könyök műtét utáni funkciójának felmérése

Mayo Elbow Functional Score (cit. 2.)

1. Fájdalom erőssége

Fájdalom

Nincs 45

Enyhe 30

Közepes 15

Erős 0

2. Mozgás

\section{Mozgás}

A mozgástartomány nagyobb mint 100 fok 20

A mozgástartomány 50 és 100 fok közötti 15

A mozgástartomány kevesebb, mint 50 fok 5

3. Stabilitás

Stabilitás

Stabil 10

Enyhén instabil 0

Nagyon instabil 0

4. Múködés

\section{Funkció}

Haját tudja fésülni 5

Sérült kezével tud enni 5

Személyes higiénés dolgokat elvégzi 5

Ingét fel tudja venni 5

Tud cipőt húzni 5

\section{MEGBESZÉLÉS}

Az alkart egységes egészként kell tekintenünk. A két csont, az ulna és a radius két végén különböző stabilizáló elemekkel összekapcsolva egységes rendszerként viselkedik a mozgás és a varus-valgus, valamint axialis erőkkel szemben.

Distalisan a radio-ulnaris szalagrendszer és a háromszögletű fibrocartillaris "discus”, míg proximalisan az ulnaris collateralis szalag, a radiusfej a ligamentum anularéval és a ligamentum quadrátum alkotják a stabilizáló rendszert (4. ábra).

A radiusfej törése gyakran szövődik a sérülés mechanizmusából adódóan a könyök dorso-radialis luxatiójával. Ilyenkor a fej törésével egyidejúleg sérül a processus coronoideus ulnae is. Ezt a hármas kombinációt nevezzük „terrible triadnak”. A törések osztályozását 1957-ben Mason adta (cit. 4). Ezt 1964-ben Johnson, valamint Broberg és Morrey kiegészítette egy IV. típussal, amely dorsoradialis luxatióval és a processus coronoideus ulnae töréssel jár (7. ábra) (3). Míg az I-II típusú törések esetén az osteosynthesis elvégezhető, addig a III-IV típusnál zömmel reszekciót végeztek.

1970 előtt, rekonstruálhatatlan radiusfej törések esetén fejreszekció volt az egyetlen megoldás. A fej eltávolítását követően az alábbi szövődmények kialakulását észlelték:

1. A valgus instabilitás jelentős fokozódása észlelhető, főleg ha a töréseket $80 \%$-ban kísérő, ulnaris collateralis szalag (UCL) szakadás is jelen van.

2. A radius proximalis migrációját figyelték meg, kifejezett csuklófájdalmat okozva.

A fej reszekció utánvizsgálata azt mutatta, 
hogy az esetek $50 \%$-ában a radius proximalis migrációja, 30\%-ban cubitus valgus, és $50 \%$ ban osteoarthritis alakul ki (7). A terrible triad fennállása esetén hiába történik meg a processus coronoideus ulnae fixációja, valamint az UCL refixációja, ha a radiusfej eltávolításra kerül, a luxatiós tendencia a fokozott instabilitás miatt megmarad. A hazai irodalomban több közlemény foglalkozik a radiusfej protézis kérdésével. A közlemények különböző anyagból készült protézissel szerzett tapasztalatokról számolnak be. A magyar nyelvű irodalomban titanium, Kovács E. (8), szilikon, Turchányi (11), izoelasztikus műanyag szárú, fém fejjel (6), valamint moduláris típusú $\mathrm{Cr}-\mathrm{Co}$, illetve titánból készült protézisekkel, Fekete K. (5) szerzett tapasztalataikról számolnak be közleményeikben. Az általunk is alkalmazott polietilénből készült, magyar gyártmányú protézisről Vidó Sándortól találtunk közleményt (12). Úgy túnik a különböző anyagok alkalmazása ellenére az ízületi porc károsodása, gyulladás generálódása nem kerülhető el. A közép és hosszú távú utánvizsgálatok hiányában az ideális anyag és protézis fajtát még nem sikerült megtalálni.

Tudomásunk szerint a fenti tények ellenére, hazánkban a radiusfej reszekciója még napjainkban is széles körben folytatott gyakorlat. Osztályunkon is ezt a gyakorlatot folytattuk, majd 2015-ben elkezdtük alkalmazni a Sanatmetal radiusfej protézist. Azóta fej reszekciót nem végeztünk.

Type I
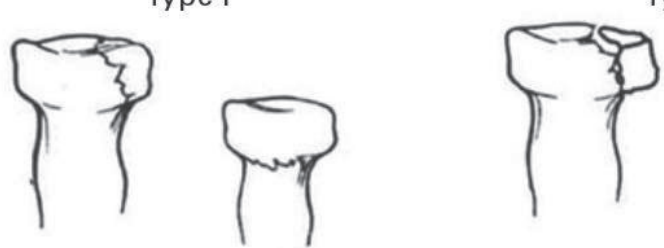

Type II

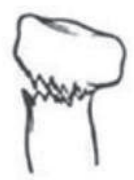

Type IV
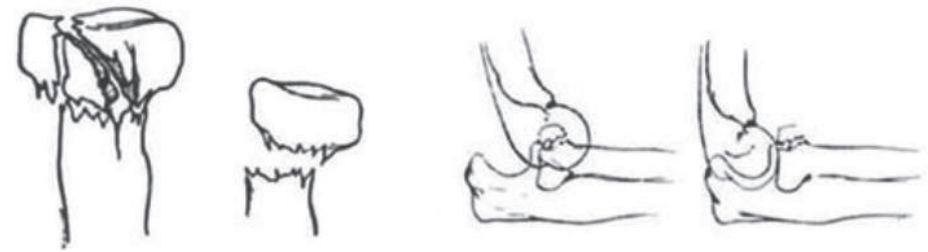

\section{7. ábra}

Mason féle törésbeosztás (cit. 3.)

\section{KÖVETKEZTETÉSEK}

Több rész radiusfej törés gyakori sérülésfajta. Többször az elkészült röntgenfelvételeken a Mason csoportba sorolás nehezen végezhető el, ezért kérdéses esetekben CT felvételek elvégzése javasolt. Az eddig elfogadott és követett rádiusfej reszekciós gyakorlat még az instabilitással nem járó törések esetén is számos nemkívánatos késői szövődmény kialakulásával jár. Instabil könyök mellett pedig súlyosbítja az instabilitásból származó szövődményeket. A fej protézisek alkalmazása már az 1970-es években kezdődött, ennek ellenére még napjainkban is jelentős számban végeznek fej reszekciókat. A radiusfej törések kezelésében az ORIF (open reduction internal fixation) prioritása nem kérdéses. A nem, vagy csak jelentős kompromisszumokkal szintetizálható, valamint az instabilitással járó törések esetén viszont véleményünk szerint a választandó módszer a radius fejecs protézis beültetés. A korai eredményeink jók. Hosszabb távú utánkövetés szükséges ahhoz, hogy a protézis beültetés helyét pontosan kijelölhessük a radius törések kezelésében. 


\section{IRODALOM}

1. Bonnevialle N.: Radial head replacement in adults with recent fractures. Orthop. Traumatol. Surg. Res. 2016. 102. (1. Suppl.): S69-S79. https://doi.org/10.1016/j.otsr.2015.06.026

2. Carità E., Donadelli A., Cugola L., Perazzini P.: Radial head prosthesis: results overview. Musculoskelet. Surg. 2017.101. (Suppl. 2.): 197-204. https://doi.org/10.1007/s12306-017-0492-x

3. Catellani F., De Caro F., Carlo F., De Biase R., Perrino V., Usai L., Triolo V., Ziveri G., Fiorentino G.: Radial head resection versus arthroplasty in unrepairable comminuted fractures Mason Type III and Type IV: A systematic review. BioMed Research International. 2018. Article ID 4020625, 12 p. https://doi.org/10.1155/2018/4020625

4. Duckworth A. D., Clement N. D., Jenkins P. J., Aitken S. A., Court-Brown C. M., McQueen M. M.: The epidemiology of radial head and neck fractures. J. Hand Surg. Am. 2012. 37. (1): 112-119. https://doi.org/10.1016/i.jhsa.2011.09.034

5. Fekete K.: Új típusú radiusfej protézis: korai eredmények: előzetes közlemény. Magyar Traumatológia Ortopédia Kézsebészet Plasztikai Sebészet. 2013. 56. (3): 199-206.

6. Fekete K., Varga I., Frenyó S.: Tapasztalataink radiusfej protézisekkel. Magyar Traumatológia Ortopédia Kézsebészet Plasztikai Sebészet. 1998. 41. (1): 29-35.

7. Johnson J. A.: Beingessner D. M., Gordon K. D., Dunning C. E., Stacpoole R. A., King G. J.: Kinematics and stability of the fractured and implant-reconstructed radial head. J. Shoulder Elbow Surg. 2005. 14. (1. Suppl. S): $195-201$. https://doi.org/10.1016/i.jse.2004.09.034

8. Kovács E., Pestessy J., Kozlovszky M.: A radius fej pótlása titánium endoprotézissel. Magyar Sebészet. 1970. 23. 405-408.

9. Morrey's B. F., Sanchez-Sotelo J.: The elbow and its disorders. 4. ed. Saunders, 2008. $1232 p$.

10. Monica J. T., Mudgal C. S.: Radial head arthroplasty. Hand Clin. $2010.26 . \quad$ (3): $403-410$. https://doi.org/10.1016/i.hcl.2010.04.008

11. Turchányi B., Cziffer E., Farkas J.: Radius fejecs protézis beültetés a friss sérülések ellátásában. Magyar Traumatológia Orthopaedia és Helyreállító Sebészet. 1990. 33. (3): 161-166.

12. Vidó S. :Új típusú radiusfej protézis. Magyar Traumatológia Ortopédia Kézsebészet Plasztikai Sebészet. 2004. 47. (2): 8389.

\section{Dr. Csonka Csaba}

3121 Somoskőújfalu, Ifjúság út 67. 


\section{Szerkesztőségi megjegyzés}

Csonka Csaba et al.: „Korai eredményeink a radiusfej töréseinek Sanatmetal protézissel való kezelésével" címú közleményéhez

A polietilén ízületi protézisekben inzertként, a csúszófelszín rugalmas biztosítására kiválóan alkalmas implantátum. Más a helyzet a tisztán, csupán múanyagból készített protézisekkel. Ahogyan a közleményt bíráló lektor is megfogalmazta: „A polietilén protézis a csont, illetve a polietilén és a hialin porc kedvezőtlen egymásra hatását, forgácsok képződését (mútét közben és azután a hosszú távú használatban), gyulladás generálódásának lehetőségét vonhatja maga után", ez alkalmazásának egyik, nem elhanyagolható problémája. A protézis körül kialakuló idegentest reakció, mint ahogyan a szilikon protéziseknél, a polietilén cementnélküli vápáknál, és könyökízületi totál protéziseknél is láttuk, alkalmazásukat erősen háttérbe szorította.

Kívánatos lenne emiatt hosszú távú utánvizsgálat végzése is, amelyre kitűnő alkalmat nyújthat a cikkben hivatkozott, 17 évvel korábban, 2002-ben lapunkhoz leadott eredeti közleményben ismertetett betegek késői eredményeinek közlése (Vidó S.: Új típusú radiusfej protézis. Magyar Traumatológia Ortopédia Kézsebészet Plasztikai Sebészet. 2004. 47. (2): 83-89.). A cikk szerzője sajnos már nem lehet közöttünk, ezért a szerkesztőbizottság a protézis megalkotóját, Bíró Csaba főorvost, ezúton is felkéri a több, mint tízéves eredmények ismertetésére. 